\title{
Microabrasion technique for enamel with fluorosis: a case report utilizing two distinct pastes
}

Técnicas de microabrasão no esmalte com fluorose: relato de caso clínico utilizando duas diferentes pastas

Carla Müller RAMOS ${ }^{1}$, Odair BIM JÚNIOR ${ }^{1}$, Ana Flávia Sanches BORGES ${ }^{1}$, Linda WANG ${ }^{1}$, Rafael Francisco Lia MONDELLI ${ }^{1}$

1 - Bauru School of Dentistry - University of São Paulo - Department of Operative Dentistry - Endodontics and Dental Materials.

\section{ABSTRACT}

The technique of enamel microabrasion is considered an aesthetic alternative conservative and effective for stain removal or surface irregularities of the enamel and different materials or pastes can be used for this purpose Objetives: The objective of this study was to compare the efficiency of the technique of enamel microabrasion using two different pastes at removing hypoplastic stains by fluorosis. Methods: The female patient, 18 years, was submitted to enamel microabrasion, and in the right half of the maxilla was manipulated in the proportion of 1:1 by volume a paste of pumice (SSWhite) and 37\% phosphoric acid (Etch Alpha, DFL), and in the left half of the maxilla used paste based on hydrochloric acid and 6.6\% silicon carbide (Micropol, DMC Equipment Ltd.). In both hemi-arches was performed the same clinical protocol and repeated three times, by the application of $1.0 \mathrm{~mm}$ thickness of paste and realized the enamel microabrasion through mechanical friction with rubber cup at low speed for $10 \mathrm{~s}$. Then, the teeth were polished with felt disc and diamond paste, and topical fluoride APF 1.23\% for 3 min was applied. Results: The clinical outcome was similar for both hemi-arches, regardless of the used technique. The success in removing stains on tooth enamel is directly related to a correct diagnosis and accurate indication of microabrasion technique. Conclusions: It can be concluded that the two pastes used in the enamel microabrasion were effective for removing intrinsic stains from fluorosis, with similar results and with the re-establishment of aesthetics of the teeth involved.

\section{KEYWORDS}

Enamel Microabrasion; Fluorosis, Dental; Paste of pumice; Phosphoric acid; Hydrochloric acid; Silicon carbide.

\section{RESUMO}

A técnica de microabrasão do esmalte é considerada uma alternativa conservadora e efetiva para remoção de manchas e irregularidades superficiais do esmalte e diferentes pastas podem ser usadas para essa finalidade. Objetivo: O objetivo desse estudo foi comparar a eficácia da técnica de microabrasão do esmalte com fluorose utilizando duas diferentes pastas. Material e Métodos: Paciente, gênero feminino, 18 anos de idade, foi submetida ao tratamento de microabrasão do esmalte, sendo que na arcada superior direita foi manipulada e aplicada a pasta à base de pedra-pomes (SSWhite) e ácido fosfórico a 37\% (Alpha Etch, DFL) na proporção de 1:1 e na arcada superior esquerda uma pasta à base de ácido hidroclorídrico a 6,6\% e óxido de silício (Micropol, DMC Equipamentos Ltda). Nas duas hemi-arcadas foi realizado o mesmo protocolo clínico por três vezes, sendo que a aplicação da pasta foi de 1 mm de espessura e a realização da microabrasão se deu por fricção mecânica com taça de borracha acoplada em baixa rotação por $10 \mathrm{~s}$. Em seguida os dentes foram polidos com disco de feltro e pasta diamantada e aplicado flúor tópico APF 1,23\% por 3 min. Resultados: Os resultados clínicos foram similares em ambas arcadas, independente da pasta utilizada. O sucesso na remoção de manchas no esmalte está dieretamente relacionada com o correto diagnóstico e a precisa indicação da técnica de microabrasão. Conclusões: Foi possível concluir que a as duas diferentes pastas utilizadas para a microabrasão do esmalte foram efetivas na remoção de machas intrínsecas por fluorose com resultados similares e com o restabelecimento estético dos dentes envolvidos.

\section{PALAVRAS-CHAVE}

Microabrasão do esmalte; Fluorose dentária; Ácido hidroclorídrico; Óxido de silício; Pedra-pomes; Ácido fosfórico 


\section{INTRODUCTION}

$\mathrm{T}$ he enamel microabrasion technique is considered an aesthetic, conservative [1,2], and effective [3] procedure, which improves the appearance of teeth with decalcified enamel defects or superficial stains $[3,4]$. The procedure results in immediate esthetic recovery of tooth aspect, usually for the long-term interval. Other advantages include: minimum enamel wear, non-invasive, feasible procedure, and non-recurrent defects after the treatment [3,58]. Microscopically, after the microabrasion, the enamel appears as a smooth surface, and therefore it result in more resistant substrate to bacterial colonization and demineralization enamel $[9,10]$.

Different microabrasion materials can be selected for stain removal $[3,11,12]$. For instance, mixture of $37 \%$ phosphoric acid and pumice $[13,14]$, mixture of $18 \%$ of hydrochloric acid and pumice $[14,15]$, and a paste containing $6.6 \%$ hydrochloric acid and silicon carbide microparticles soluble in water are utilized $[3,16]$. The treatment can be performed alone or associated with other cosmetic procedures such as tooth whitening [1-17] and composite resin restorations $[19,20]$.

Fluorosis is a disease whose signs include white stains on the enamel surface that can be successfully treated with microabrasion techniques $[21,22]$. The ingestion of high doses of fluoride from fluoridated water, toothpastes, and mouth rinses during teeth germ growth might cause staining $[22,23]$. The size/depth of stains might decrease after enamel microabrasion and even the fluorosis lesions is not completely removed by microabrasion, this technique appears advantageous because the resulting in polishing or glaze enamel, may end up hiding the surface residual defect, due to its optical property of reflecting and refract light $[1,3,23]$.

The success of microabrasion is related to the type and size of stains [7] and requires knowledge of the cause of stains and mastery of the techinique [24]. Since the microabrasion is performed on the surface of enamel, the smaller the lesion the higher the chances for a successful treatment [25].
The purpose of this manuscript was to report a clinical case related to Flurosis treated with two distinct microabrasion pastes.

\section{CASE REPORT}

A healthy 18-year-old woman sought treatment reporting esthetic discomfort on the maxillary teeth due to the presence of widespread white stains. After a detailed clinical history and examination, we obtained the diagnosis of mild fluorosis (Dean classification) [26] or TF degree 3 (Thylstrup and Fejerskov classification) [27] (Figure 1). Even though these stains also affected the mesial face of upper canines, the patient did not complain about these stains and therefore, the enamel microabrasion was the chosen treatment on the maxillary teeth, which appears on her smile. As patient will be submitted to orthodontic treatment, tooth movement would result in covering these faces.The response rate was $80 \%(n=436)$. Reasons for nonparticipation were lack of interest $(50 \%)$, health problems (19\%), lack of time (23\%) and other reasons $(8 \%)$.

The clinical procedures prior to microabrasion included: 1) preparation of the operative field with rubber dam and clamps placed on the maxillary first molars (Figure 2); 2) The rubber dam was placed and held in the dental sulcus of the involved teeth with the aid of ligatures, in order to protect the adjacent soft tissues (Figure 3); 3) The teeth were subjected to prophylaxis with a brush and abrasive paste (Herjos F - Vigodent, Rio de Janeiro, RJ, Brasil) followed by rinsing with water (Figure 4).

A paste with $37 \%$ phosphoric acid gel and pumice was applied to the patient's maxillary left hemi-arch. The paste was prepared with a $1: 1$ volume rate. The two components were divided into three portions on a glass plate in preparation for mixing and applying (Figure 5). Another paste consisting of $6.6 \%$ hydrochloric acid and silicon carbide (Micropol, DMC Equipamentos Ltda., São Carlos, SP, Brazil), which is a commercially available material packaged in a syringe, was applied to the maxillary right hemi-arch.

The same clinical protocol was performed in both hemi-arches, with a $1.0 \mathrm{~mm}$ thickness of paste applied over the stained area of each tooth (Figure 6), extending the stained area to buccal and interproximal faces. 
The microabrasion procedure was performed through mechanical friction utilizing a rubber cup (Microdont, São Paulo, SP, Brazil) at a low speed for $10 \mathrm{~s}$ (Figure 7) on each tooth. After each microabrasion, the paste was rinsed with water to neutralize and remove the microabrasion pastes (Figure 8).

The results were evaluated by careful assessment of buccal, incisal and occlusal surfaces, to observe the amount of enamel

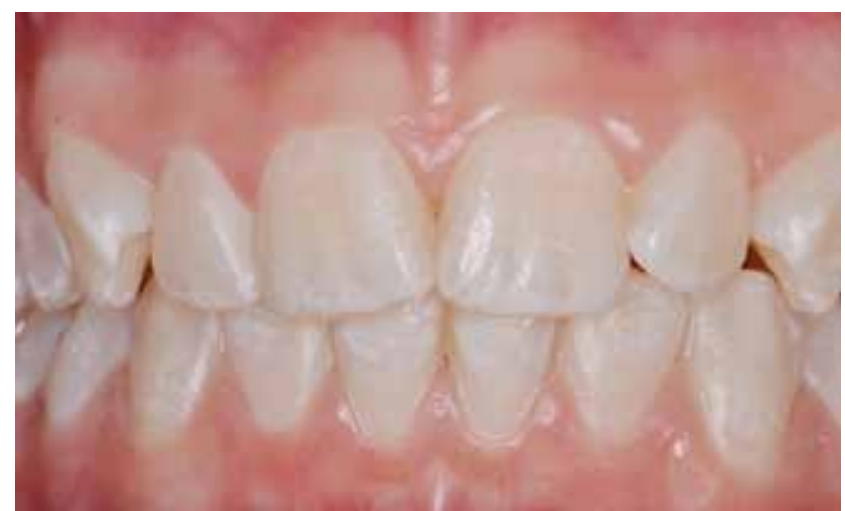

Figure 1 - Initial appearance of smile revealing white spots.

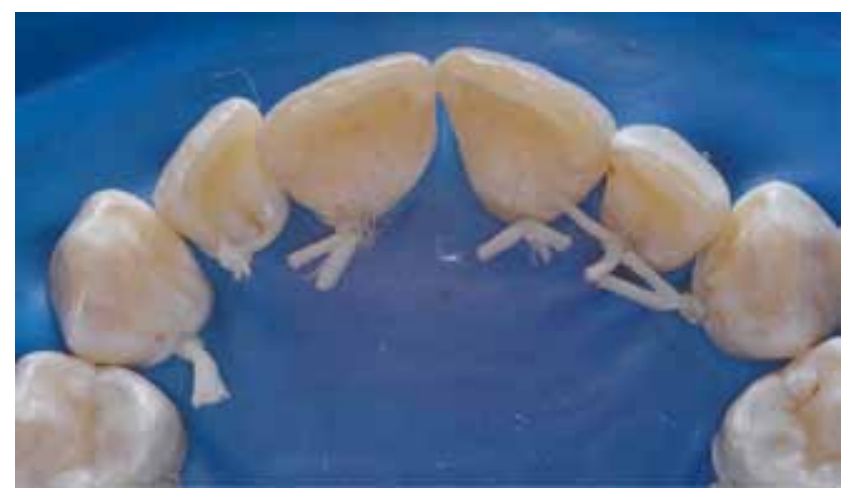

Figure 3 - Reinforcement of rubber dam with dental floss.

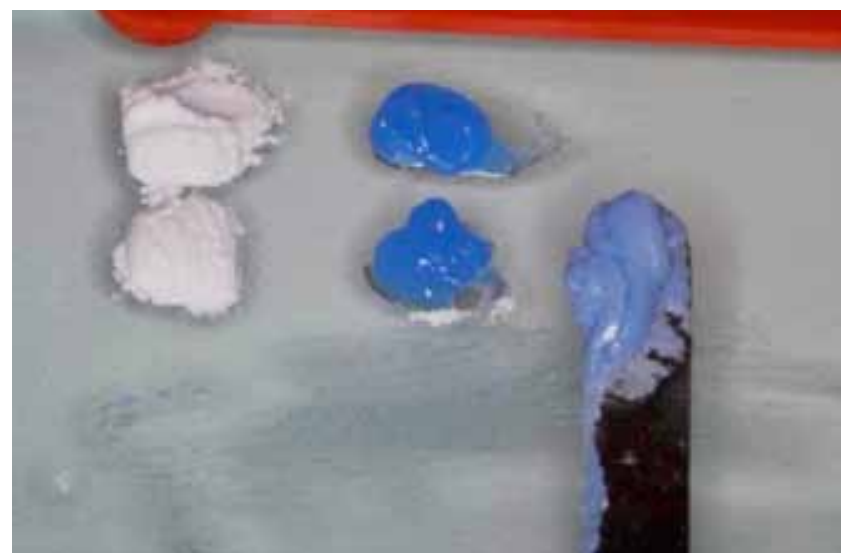

Figure $\mathbf{5}$ - Manipulation of $37 \%$ phosphoric acid and pumice paste (1:1 volumetric proportion). wear. The same microabrasion protocol was repeated three times. Even after microabrasion, the mesial side of the maxillary canines showed visible white spots but the patient felt satisfied with the result. Afterwards, the polishing was performed on the abraded enamel using felt discs with polishing paste (F Herjos - Vigodent, Rio de Janeiro, RJ, Brazil) (Figure 9), followed by a $1.23 \%$ acidulated phosphate fluoride gel application for $3 \mathrm{~min}$ (Figure 10).

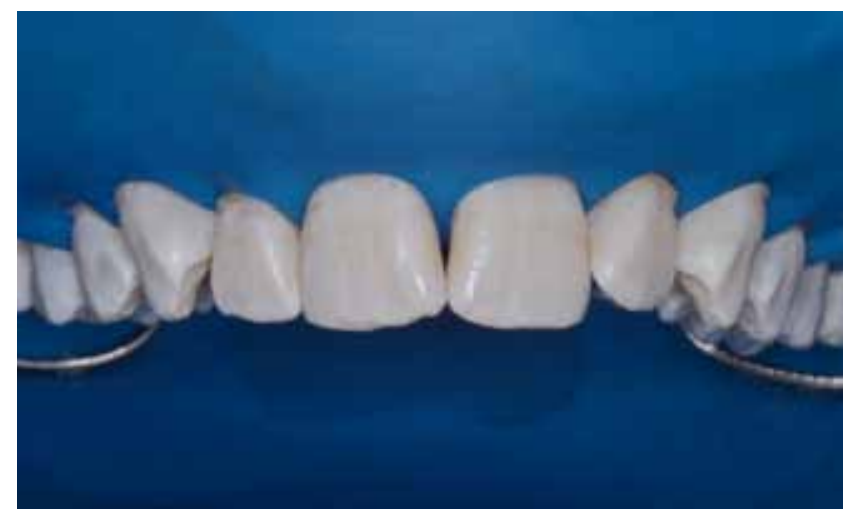

Figure 2 - Use of rubber dam to optimize visualization and protect gum.

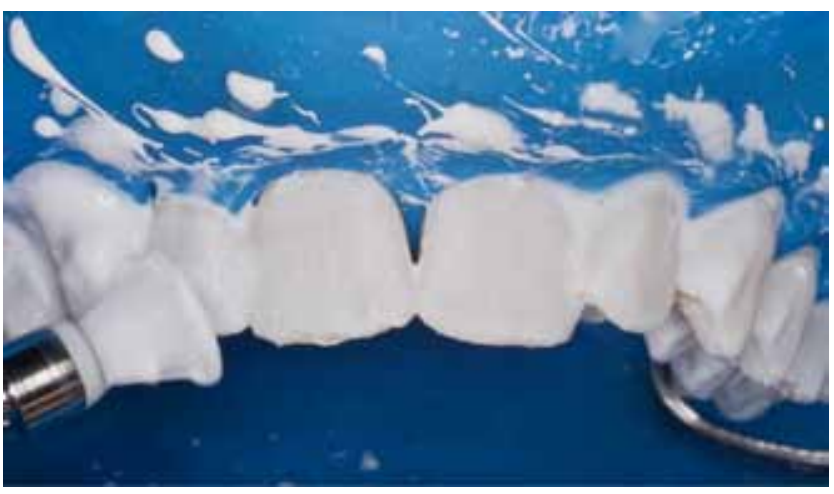

Figure 4 - Prophylaxis with brush and prophylactic paste.
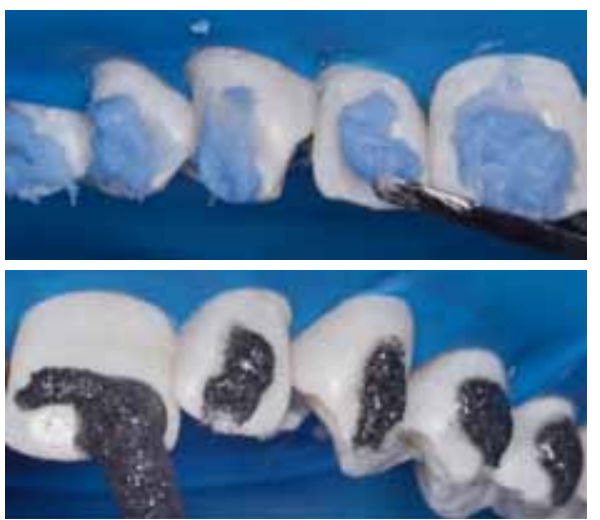

Figure 6 - Application of abrasive pastes. A) Above: $35 \%$ phosphoric acid and pumice; B) Below: hydrochloric acid and silicon carbide paste (Micropol). 

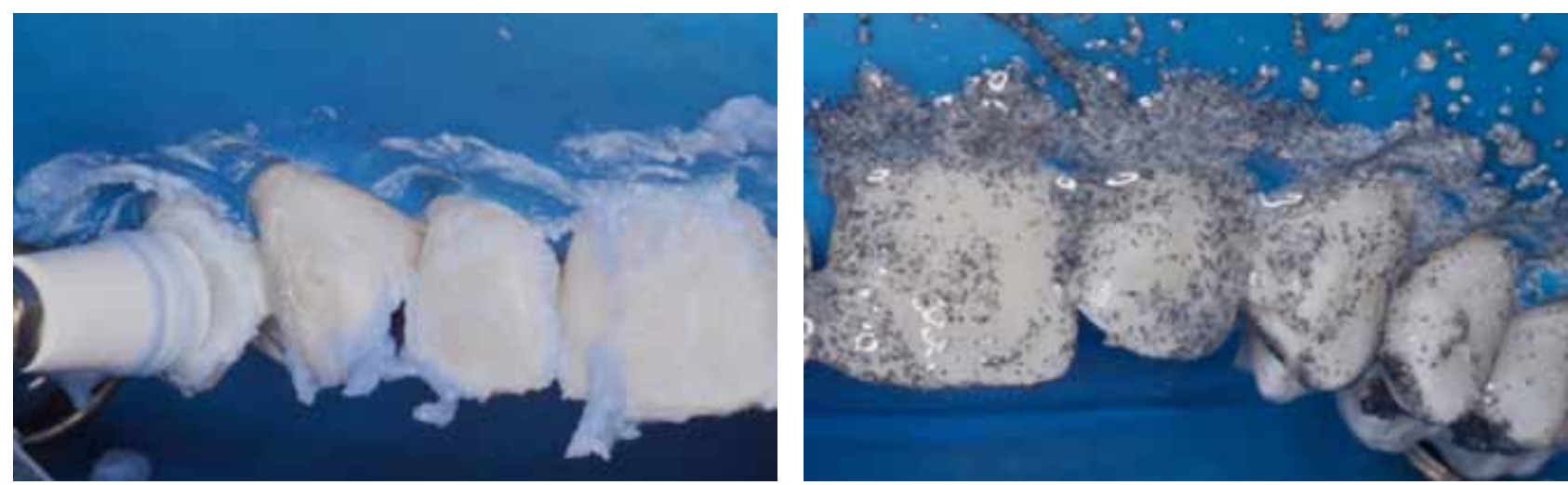

Figure 7-Mechanical friction with rubber cup at low speed.
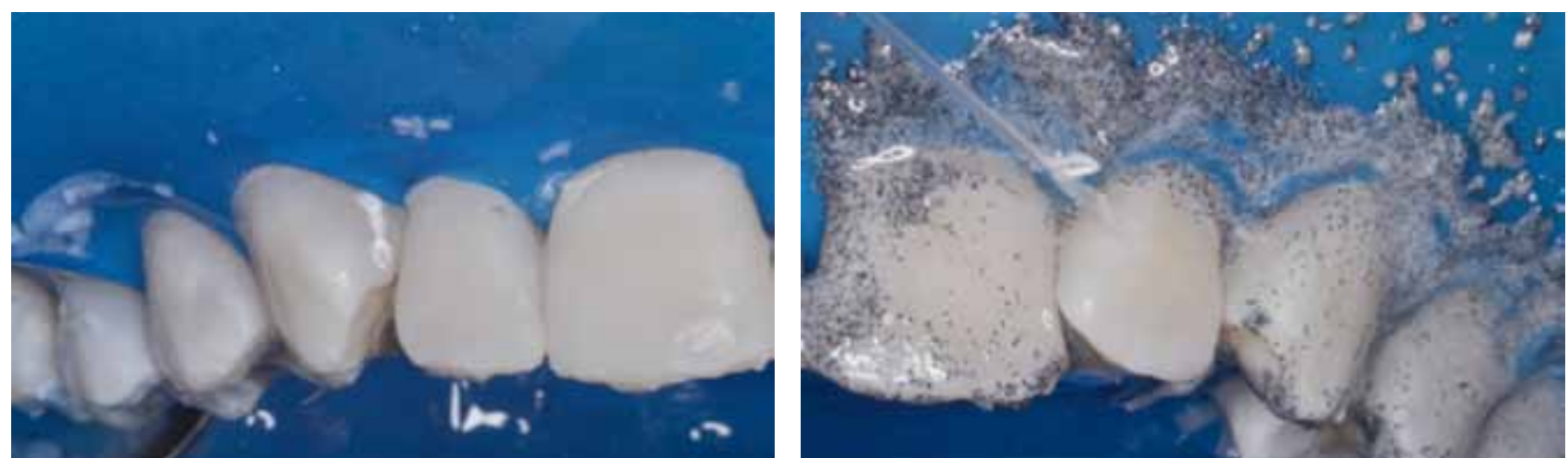

Figure 8 - Washing with water, with care to remove all material.

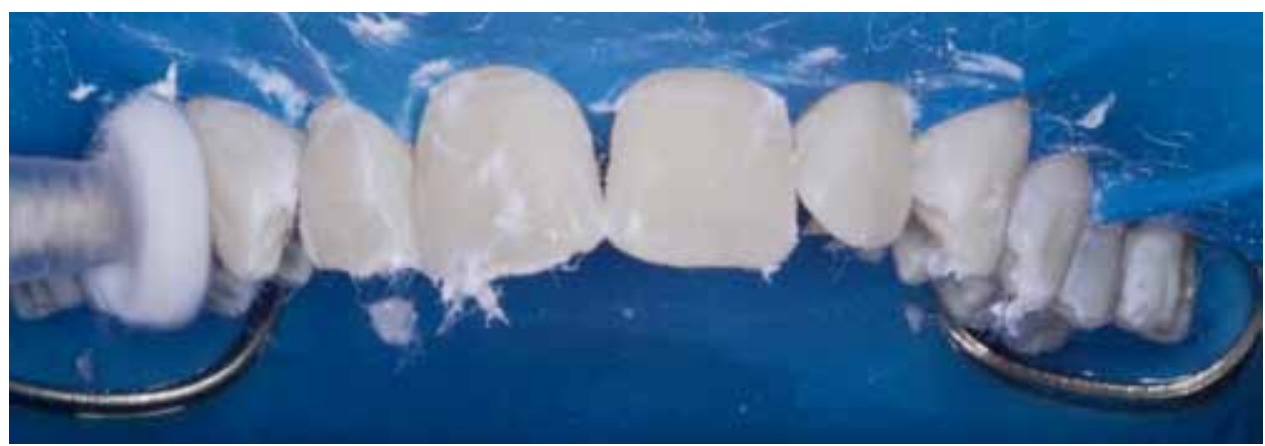

Figure 9-Polishing with felt disc and prophylaxis paste.

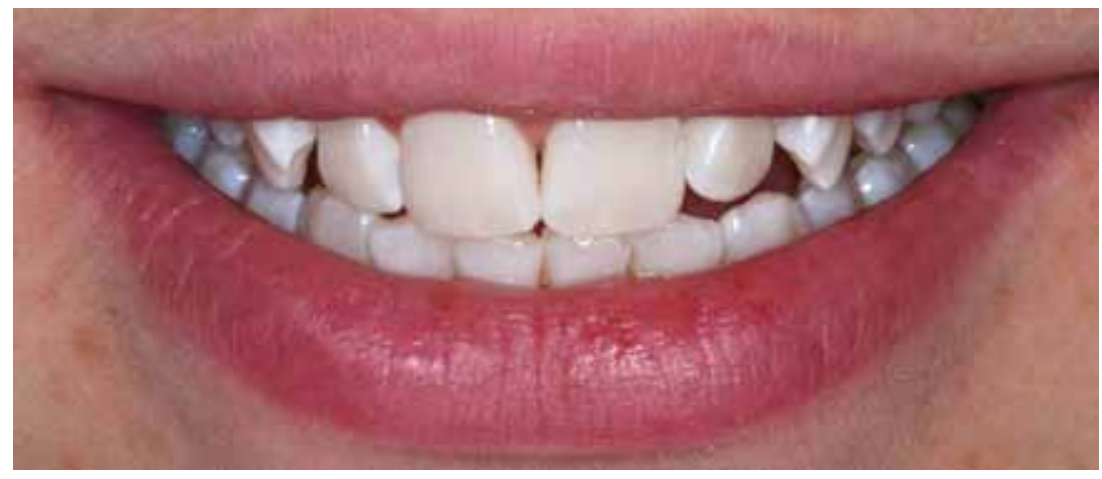

Figure 10 - Immediately final result. 


\section{DISCUSSION}

The microabrasion technique is considered minimally invasive procedure $[1,3,4]$. Special care is needed during the procedures to avoid removing extra tooth structure. The microabrasion treatment of selected cases requires the correct disease diagnosis [28]. A variety of etiologies can cause color changes in the dental enamel. Since the aim of microabrasion treatment is to preserve healthy tooth structure, the esthetic result might be a consequence of a successful superficial enamel removal.

The concentration and time of used acid significantly influences the superficial enamel removal because the demineralization degree is directly dependent on it [3]. The acids associated with course particles increase the abrasive potential, removing the enamel irregularities of fluorosis stains [29]. Other factors related to the microabrasion technique besides the pastes influenced the results, such as: the instrument of paste application and its mode (manually or mechanically applied). However, it must be highlighted that regardless of the type of instrument utilized, the surface roughness of the enamel will always be increased [30].

Comparing the two pastes utilized for the enamel microabrasion in this case report, an immediate improvement on esthetics of the smile was observed in all treated surfaces, with less evident stains. Despite the successful case reports of fluorosis treated with microabrasion $[1,31]$ and the positive perspectives of the in vitro studies regarding this issue $[1,12,30]$, the literature provided few reports comparing the effects of different pastes utilized in the microabrasion techniques [3].

The maintenance of esthetic is a critical concern after microabrasion of fluorosis stains [28]. The number of sessions or paste applications might promote an "artificial" appearance of the enamel surface, as a result of excessive smoothness [30], as reported with six manual applications of abrasive slurry (6\% hydrochloric acid and silicon carbide). In this case report, the performance of both treatments resulted in optimized esthetic with three mechanical applications with lowspeed rubber cup [32]. The combination of high acid concentrations with abrasive particles are associated with fewer number of paste applications. Regardless of the different paste types and the mechanical applications utilized, the current results showed that care is needed to choose microabrasion techniques because of the cost and the aggressiveness of the procedure.

\section{CONCLUSION}

It can be concluded that the two pastes utilized in the micro-abrasion technique in this case report were effective in removing intrinsic stains caused by fluorosis, thus creating similar results and an acceptable esthetic teeth establishment. If a correct diagnosis is performed, then microabrasion can reach satisfactory results involving minimal wear.

\section{REFERENCES}

1. Nahsan FP, da Silva LM, Baseggio W, Franco EB, Francisconi PA, Mondelli RF, et al. Conservative approach for a clinical resolution of enamel white spot lesions. Quintessence Int. 2011 May;42:423-6.

2. $\mathrm{Ng} \mathrm{F}$, Manton DJ. Aesthetic management of severely fluorosed incisors in an adolescent female. Aust Dent J. 2007;52:243-8.

3. Rodrigues MC, Mondelli RFL, Oliveira GU, Franco EB, Bassegio W, Wang L. Minimal alterations on the enamel surface by micro-abrasion: in vitro roughness and wear assessments. J Appl Oral Sci. 2013;21(2):112-7.

4. Allen $\mathrm{K}$, Agosta C, Estafan D. Using microabrasive material to remove fluorose stains. J Am Dent Assoc. 2004;135:319-23.

5. Croll TP. Enamel microabrasion. Chicago: Quintessence;1991.

6. Haywood VB, Heymann HO. Nightguard vital bleaching. Quintessence Int. 1989; 20(3):173-6

7. Sundfeld RH. Novas considerações clínicas sobre microabrasão do esmalte dental: efeitos da técnica e tempo de análise. Rev Bras Odontol. 1995;52(3):30-5.

8. Tong LS, Pang MK, Mok NY, King NM, Wei SH. The effects of etching, microabrasion, and bleaching on surface enamel. J Dent Res. 1993;72(1):67-71

9. Croll TP. Enamel microabrasion: Observations after 10 years. J Am Dent Assoc. 1997;128:45S-50S. Taifour D, Frencken JE, Beiruti N, van't Hof MA, Truin GJ, van Palenstein Helderman WH. Comparison between restorations in the permanent dentition produced by hand and rotary instrumentation-survival after 3 years. Community Dent Oral Epidemiol. $2003 \mathrm{Apr} ; 31(2): 122-8$.

10. da Silva SM, de Oliveira FS, Lanza CR, Machado MA. Esthetic improvement following enamel microabrasion on fluorotic teeth: $A$ case report. Quintessence Int. 2002;33:366-9.

11. McEvoy AS. Chemical agents for removing intrinsic stains from vital teeth. II Current techiniques and their clinical application. Quintessence Int. 1989;20(6):379-84. 
12. Moura LFAD, Mendes SNC, Moura WL. Microabrasão do esmalte: avaliação clínica. J Bras Clin Estet Odont. 2000;4(21):83-8.Tyas MJ. Milestones in adhesion: glass ionomer cements. J Adhes Dent. 2003;5:259-66

13. Mondelli RFL, Mondelli J, Bastos MTAA, Franco ED. Microabrasão com ácido fosfórico. Rev Bras Odontol. 1995;52(3):20-2

14. Meireles SS, Andre D de A, Leida FL, Bocangel JS, Demarco FF. Surface roughness and enamel loss with two microabrasion techniques. J Contemp Dent Pract. 2009;10(1):58-65

15. Waggoner WF, Johnston WM, Schumann S, Schikowski E. Microabrasion of human enamel in vitro using hydrochloric acid and pumice. Pediatr Dent. 1989;11:319-23.

16. Ardu S, Stavridakis M, Krejci I. A minimally invasive treatment of severe dental fluorosis. Quintessence Int. 2007;38:455-8.

17. Higashi C, Dall'Agnol AL, Hirata R, Loguercio AD, Reis A. Association of enamel microabrasion and bleaching: a case report. Gen Dent. 2008 May;56(3):244-9

18. Bertassoni LE, Martin JM, Torno V, Vieira S, Rached RN, Mazur RF. In-office dental bleaching and enamel microabrasion for fluorosis treatment. J Clin Pediatr Dent. 2008 Spring;32(3):185-7.

19. Croll TP. Combining resin composite bonding and enamel microabrasion. Quintessence Int1996;27(10):669-71.

20. Apayco LCC, Baseggio W, Franco EB, Mondelli RFL. Tratamiento de la pigmentación sistémica y la fluorosis por medio de blanqueamiento en consultorio asociado a microabrasión de esmalte. Acta Odontol Venezolana. 2010;48:1-15.

21. Mclnnes J. Removing brown stain from teeth. Ariz Dent J. 1966:12(4):13-5.

22. Rock WP, Sabieha AM. The relationship between reported toothpaste usage in infancy and fluorosis of permament incisors. Brit Dent J.1997;183(5):165-70.
23. Paixão RF, Paiva SM, Carcereri DL, Capella LF, Silva RHH. Clareamento de dentes manchados pela fluorose / Bleaching of the mottled teeth by fluorosis . RGO. 1990; 38(2):83-6

24. Reston EG, Corba DV, Ruschel K, Tovo MF, Barbosa NA. Conservative approach for esthetic treatment of enamel hypoplasia. Oper Dent. 2011 May-Jun;36(3):340-3.

25. Wong FS, Winter GB. Effectiveness of microabrasion technique for improvement of dental aesthetics. Br Dent J. 2002 Aug 10;193(3):155-8

26. Dean HT. Classification of mottled enamel diagnosis. J Am Dent Assoc. 1934;21:1421-6

27. Thylstrup A, Fejerskov 0. Clinical appearance of dental fluorosis in permanent teeth in relation to histological changes. Community Dent Oral Epidemiol. 1978;6(6):315-28.

28. Paic M, Sener B, Schug J, Schmidlin PR. Effects of microabrasion on substance loss, surface roughness, and colorimetric changes on enamel in vitro. Quintessence Int. 2008;39:517-22.

29. Donly KJ, ONeill M, Croll TP. Enamel microabrasion: a microscopic evaluation of the "abrasion effect". Quintessence Int. 1992;23(3):175-9

30. Zuanon ACC, Azevedo ER, Santos-Pinto LA. Rugosidade superficial de dentes decíduos e permanentes após a utilização da técnica de microabrasão. Rev Odontol Unesp. 2008;37:100.

31. Benbachir N, Ardu S, Krejci I. Indications and limits of the microabrasion technique. Quintessence Int. 2007;38:811-5.

32. Marson FC, Sensi LG, Araújo F0. Clareação dentária associada à microabrasão do esmalte para remoção de manchas brancas. Revista Dental Press Estética. 2007;4(1):89-96.

\section{Carla Müller Ramos}

(Corresponding address)

Faculdade de Odontologia da USP

Av. Professor Lineu Prestes, 2227 - Cidade Universitária

05508-000 - São Paulo - SP - Brasil

Date submitted: 2013 Apr 13

E-mail address: carla.muller@usp.br 